\title{
THE ANALYSIS OF BEKASI INDUSTRIAL TOURISM'S BRAND AWARENESS
}

\author{
Kristian Sulistio $^{1}$, Yunita Ismail ${ }^{2}$ \\ President University, Bekasi, Indonesia \\ kristian110396@gmail.co.id \\ yunitaismail@president.ac.id
}

\begin{abstract}
ABSTRAK
Sebagai bagian dari pengembangan pariwisata Bekasi, Dinas Pariwisata Kabupaten Bekasi memiliki target untuk mendatangkan 2 juta wisatawan ke Bekasi pada tahun 2018. Kabupaten Bekasi sendiri adalah kawasan industri terbesar di Asia Tenggara dengan perkiraan 4000 industri. Melihat potensi ini, Dinas Pariwisata Kabupaten Bekasi dan Jababeka membentuk konsep yang disebut Wisata Industri Bekasi. Penelitian ini bertujuan untuk menganalisis strategi promosi yang paling efektif dalam menciptakan kesadaran merek terhadap Wisata Industri Bekasi. Penelitian ini menggunakan metode penelitian kuantitatif untuk mengevaluasi variabel independen (Iklan, penjualan pribadi dan pemasaran media sosial) terhadap variabel dependen (Kesadaran merek). Non-probability sampling dengan purposive sampling digunakan dalam penelitian ini. Kuisioner yang terdiri dari 21 pertanyaan dengan skala likert sebagai alat untuk mengukur tingkat kesepakatan dibagikan kepada 125 responden. Analisis data yang digunakan dalam penelitian ini adalah validitas, reliabilitas, asumsi klasik dan regresi berganda. Hasilnya menegaskan bahwa iklan, penjualan pribadi, dan pemasaran media sosial memiliki pengaruh signifikan sebagian pada kesadaran merek. Pemasaran media sosial memiliki pengaruh tertinggi pada kesadaran merek diikuti oleh penjualan pribadi dan periklanan. Penelitian ini juga menunjukkan bahwa semua variabel independen (iklan, penjualan pribadi, dan pemasaran media sosial) memiliki pengaruh signifikan secara simultan terhadap kesadaran merek dengan $75 \%$ dari $R^{2}$ yang disesuaikan.
\end{abstract}

Kata kunci: Periklanan, penjualan pribadi, pemasaran media sosial, kesadaran merek, pariwisata industri

\section{ABSTRACT}

As the part of tourism development of Bekasi, Tourism Office of Bekasi Regency has a target to bring 2 million tourists to Bekasi in 2018. Bekasi Regency itself is the largest industrial park in Southeast Asia with the estimated 4000 industries. Seeing this potential, Tourism Office of Bekasi Regency and Jababeka form a concept called Bekasi Industrial Tourism. This study aimed to analyze the most effective promotion strategies in creating the brand awareness of Bekasi Industrial Tourism. This research used a quantitative research method to evaluate the independent variables (Advertising, Personal Selling and Social Media

\footnotetext{
${ }^{1}$ Alumni of Business Faculty, President University

${ }^{2}$ Lecturer of Engineering Faculty, President University
} 
Marketing) towards dependent variable (Brand Awareness). Non-probability sampling with purposive sampling was used in this study. Questionnaires consisting of 21 questions with the Likert scale as a tool to measure the level of agreement was distributed to 125 respondents. Data analysis used in this research were validity, reliability, classical assumption and multiple regression. The result affirmed that advertising, personal selling, and social media marketing have a partial significant influence on brand awareness. Social media marketing has the highest influence on brand awareness followed by personal selling and advertising. This study also showed that all independent variables (advertising, personal selling, and social media marketing) have simultaneous significant influence towards brand awareness with $75 \%$ of adjusted $\mathrm{R}^{2}$.

Key words: Advertising, personal selling, social media marketing, brand awareness, industrial tourism

\section{A. Introduction}

Tourism industry has a good impact on regional development. The visits of tourists have a significant effect to increase of regional income (Wulandari \& Triandaru, 2014). Besides that, tourist expenditure itself can increase the welfare of the local population. This is accordance to Suastika and Yasa (2017) that stated, the consumptive activities of foreign and domestic tourists will increase the income of the tourism sector which will ultimately drive the ability of the tourism industry to improve the welfare of the local population in the districts.

In addition, the successful development of the tourism sector will also improve the financial performance of the regions which will increase the income per capita, public education and life expectancy (Widiastuti, 2013).

In regional development and tourism development efforts, Tourism Office of Bekasi Regency has a target to bring 2 million tourists to Bekasi Regency in 2018 whereas the existing tourist destination only predicted can attract 1 million tourists (Susanto, 2017). So as to achieve the target, it seems necessary to add new tourist destination that unique and different from the tourist destination that usually exists in Indonesia which can attract the tourist's attention to come to Bekasi Regency.

If we look and see the potential in Bekasi Regency, the first thought is the industry. In 2017, there are 1950 industries in Jababeka (Jababeka Industrial Estate, 2017). Beside Jababeka there are 7 others industrial estate in Bekasi Regency, namely Delta Silicon, Bekasi International Industrial Estate (Hyundai Industrial Estate), Greenland International Industrial Center, Karawang International Industrial City, Megapolis Manunggal 2100, Bekasi Fajar Industrial Estate and East Jakarta Industrial Park which makes Bekasi Regency as the largest Industrial park in Southeast Asia with total estimation $+/$ - 4000 multinational industries (Hariyanto, 2018). 
Seeing this potential, Jababeka in collaboration with Tourism Office of Bekasi Regency formed a concept called Bekasi Industrial Tourism (Susanto, 2017). Industrial tourism itself can be found in countries such as France, UK, and German (Lee, 2015). In Taiwan, Industrial Tourism has grown rapidly as 145 factories have been set to provide an opportunity for tourist to visit, be entertained, be educated and get to know about the products (Chow et al., 2016).

The Founder of Jababeka, Mr. Darmono explained that Bekasi Industrial Tourism (BIT) will be experience learning or outing class that can restore the essence of the study tour that should put forward the value of education filled with fun \& joy (Hariyanto, 2018). The support also has been shown by the minister of tourism Indonesia, Arief Yahya as he believes that Industrial Tourism in Indonesia has huge potential and will definitely growth if it is done seriously like the Industrial Tourism in Japan that has become the one of the main selling of their tourism industry (Kusumawardhani, 2018).

Survey have been conducted to 30 teachers of 30 Schools in Jabodetabek by Bekasi Industrial Tourism asking about their awareness of Bekasi Industrial Tourism. The result showed that there were only 2 teachers out of 30 teachers that aware Bekasi Industrial Tourism. The brand awareness of people about the Bekasi Industrial Tourism itself can be a problem for Bekasi Industrial Tourism to invite the tourist to visits. This is according to Maulana (2014) that stated the brand awareness in tourism will be important to provide the image of tourism and increase the number of tourist visits.

Many ways and strategies are applied in order to attract tourists. Various marketing and promotion ways as well as management tools that can be considered for implementation. Bekasi Industrial Tourism itself focuses on the promotion such as advertising through spreading flyers, personal selling through direct face to face communication with prospective customers, and social media marketing which has become one of the promotional media used by many companies in the present.

The effective promotion strategies will be able to establish brand awareness about the existence of a product or service (Warni, 2015). And in this case is the awareness of Bekasi Industrial Tourism's brand as the industrial tourism in Bekasi. Certainly it is very important in making measurements on the promotion that has been done Bekasi Industrial Tourism so that later the results of this research can eventually be the basis for developing the promotion of Bekasi Industrial Tourism to increase more brand awareness to people. 


\section{B. Literature Review}

\section{Brand Awareness}

Brand Awareness is the ability of the brand to be recognized or recall by the customers when they are thinking of particular product. Brand awareness can be separated by two which is brand recognition and brand recall (Kotler \& Keller, 2011). While according to Surachman on Sudarsono et al., (2013), brand awareness is the ability of a person which is a potential buyer to recognize or recall a brand that is a part of the product category. Huang \& Sarigöllü (2011) added that brand awareness affects customers to make their decisions that will ultimately reinforce the brand's performance in the marketplace.

Based on the definition of expert opinion above, it can be concluded that the brand awareness is the ability of a potential buyer in recognizing the return of the brand in the product. In essence, people will not buy products that they do not know. But the buyers are much comfortable with familiar products compared to unknown products.

\section{Advertising}

According to Shimp \& Andrews (2012), advertising is all the form that is used to communicate with the recipient of the message with the aim of inviting them to buy certain products or services right now or in the future. Advertising includes communication in the form of products, services, and ideas paid by identified sponsors.

Advertising does not merely convey information about a commodity (objects or services) but has the nature of encouraging and persuading the customer to like, choose and buy it. According to Kusumawati (2010), advertising is an activity of delivering the news submitted on the order of the parties who want the product or service in question favored, selected and purchased. Sawant (2012) in his research stated that advertising provides support to potential consumers who have doubts to buy a product so that the prospect's doubts will diminish and eventually will be sure and buy the product.

According to Kotler \& Keller (2011), the informative advertising can create the brand awareness of new products. Besides that, Advertising also can maintain brand awareness. According to Shimp \& Andrews (2012), advertising usually is designed also for developing brand awareness. Herdana (2015) found that there is a significant positive relationship between advertising and brand awareness. Advertising is a means to help effective marketing in establishing communications between companies and consumers in an attempt to establish 
brand awareness. The more quality advertising activities conducted by the company can increase the brand awareness that is formed in the mind of the customer.

\section{Personal Selling}

According to Shimp \& Andrews (2012), personal selling is a form of individual communication whereby a salesperson deals with potential buyers by determining their needs and seeks to influence them to buy their products or services. In an effort to reach consumers, personal selling can be face-to-face communication and phone sales to online contacts depending on the situation.

Suparwo et al., (2017) stated that personal selling is a very dominant role in promotional activities of a company because with personal selling the seller can communicate directly with consumers. The use of personal selling varies greatly from organization to organization, depending on a number of factors, such as the characteristics of a marketable product or service, the size of the organization, and the type of industry.

Kusumadmo on Matta (2016) stated that in personal selling, salesperson can directly know the needs, desires, motives, complaints, and consumer behavior. so sellers can make adjustments to messages delivered to buyers according to the unique characteristics of each prospect.

Dewi \& Madgalena (2017) found that personal selling significantly influences brand awareness. The more often the business do personal selling activities, then the brand awareness on the business both products and services are also increasing. Another research conducted by Wijaya (2010) also found that the personal selling has a positive influence towards brand awareness. The knowledge of the salesman can increase the brand awareness of the customer. Kusnadi (2010) also added that the systematic communication of personal selling can make the customer more aware of the brand.

\section{Social Media Marketing}

According to Shimp \& Andrews (2012), social media marketing is a form of electronic communication that the user can share the content such as information, ideas, and videos within the user's social network. According to Tsitsi (2013), social media marketing is the use of a system that allows markets to engage with each other to collaborate and interact with the intelligence of those who participate in it for the purpose of marketing products and services. Chary (2014) stated that social media marketing refers to the process of getting 
attention by getting website visits or social media sites. Media marketing programs are centered and strive to attract attention by creating engaging content that encourages readers to share it with their social networks. Refers to the statement of several experts, social media marketing is a marketing strategy that uses social media to market a product or service by utilizing those who participate in it for marketing purposes.

Adiguna (2016) found that there is a significant influence of social media marketing towards brand awareness. The company has to build a strong involvement in social media with their customers because this can encourage the potential customer to think that their brand has a certain quality and worth to buy. Another research conducted by Melati (2016) found that social media that used for marketing have a strong correlation and influential on the brand awareness. The company has to pay attention to the quality of content uploaded in their social media because it can affect the perspective on the customer's mind about the quality of the brand. Adding from Looy (2016), Social media can be used by the organization to create value in term of brand awareness to their potential customers.

\section{Theoretical Framework}

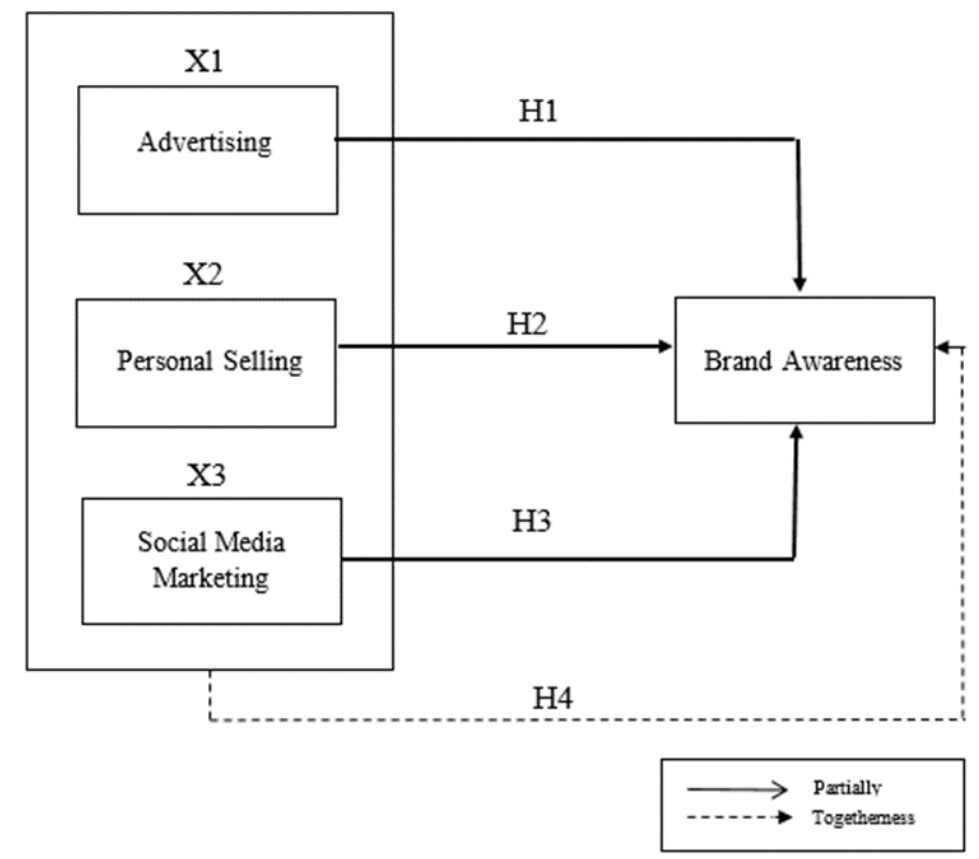

Figure 1. Theoretical Framework

\section{Methodology}

\section{Research Method}

Research methodology is a scientific way based on the characteristics of: rational, empirical and systematic that used to conduct a research (Sugiyono, 2013). According to Sujarweni 
(2015), research method can be quantitative (as generally gathered through structured questions) or qualitative (as generated from the broad answers to specific questions in interviews, or from responses to open-ended questions in a questionnaire, or through observation, or from already available information gathered from various sources).

Quantitative research is a study that produces findings that can be obtained by using statistical procedures or by means of quantification or measurement. Quantitative approaches focus on symptoms that have certain characteristics in human life called as variables. In quantitative research, the nature of relationships among variables is analyzed by using objective theory. The result of the quantitative method is generalized findings that can be applied to other populations.

The quantitative method was used in this research. According to Sujarweni (2015), quantitative research limits the scope of research by identifying one or several variables and measuring the relationship between one thing (independent variable) and another thing (dependent variable) in population. The characteristics of quantitative research are using statistics as a means of determining samples, validity and reliability instrument testing, data presentation and data analysis (Sugiyono, 2013).

\section{Research Design}

Questionnaires consisting of 21 questions with the Likert scale as a tool to measure the level of agreement was distributed to 125 respondents. The population in this study are people that already see the promotion of Bekasi Industrial Tourism based on advertising, personal selling, and social media marketing.

Non probability sampling was used in this research. According to Surjaweni (2015), non probability sampling is the sampling techniques that do not give equal opportunities to each element or member of the population to be the sample. There are some advantages of using non probability sampling such as easy to use, time efficient and cost effectiveness. In addition, the researcher use purposive sampling. According to Sugiyono (2013), purposive sampling is a technique of determining the sample with certain considerations and certain criteria. The advantage of purposive sampling is that the data obtained later can be more representative and in accordance with the purpose of research (Ulwan, 2014). 


\section{Results and Discussions}

1 Results

\subsection{Respondent Profile}

Table 1. Respondent Profile

\begin{tabular}{|c|c|c|}
\hline Descriptions & Frequency & Percent $(\%)$ \\
\hline \multicolumn{3}{|l|}{ Gender } \\
\hline Male & 72 & $57.60 \%$ \\
\hline Female & 53 & $42.40 \%$ \\
\hline \multicolumn{3}{|l|}{ Age } \\
\hline$<21$ Years Old & 33 & $26.40 \%$ \\
\hline 21-30 Years Old & 52 & $41.60 \%$ \\
\hline 31-40 Years Old & 25 & $20 \%$ \\
\hline$>40$ Years Old & 15 & $12 \%$ \\
\hline \multicolumn{3}{|l|}{ Last Education } \\
\hline Junior High School & 18 & $14.40 \%$ \\
\hline Senior/Vocational High School & 31 & $24.80 \%$ \\
\hline Bachelor & 75 & $60 \%$ \\
\hline Master & 1 & $0.80 \%$ \\
\hline \multicolumn{3}{|l|}{ Occupation } \\
\hline Student & 18 & $14.40 \%$ \\
\hline Univ Student & 42 & $33.60 \%$ \\
\hline Employee & 32 & $25.60 \%$ \\
\hline Entrepreneur & 33 & $26.40 \%$ \\
\hline
\end{tabular}

There are 53 female and 72 male respondents which are the majority who answered the questionnaires. The second category of the respondent profile is the age of the respondents, Most of the people that already see the promotion of Bekasi Industrial Tourism is 21-30 years old with 52 respondents. Followed by $<21$ years old with 33 respondents, 31-40 years old with 25 respondents and $>40$ with 15 respondents. The third category is last education, there are 75 respondents come from bachelor, 31 respondents come from senior high school or vocational high school, 18 respondents come from junior high school and 1 respondent come from the master. The last category is Occupation, It can be seen that most of the people that already see the promotion of Bekasi Industrial Tourism is university students with 42 respondents. Followed by an entrepreneur with 33 respondents, employee with 32 respondents and student with 18 respondents. 


\subsubsection{Multiple Regression}

Based on Table 2 Result of Multiple regression, the result of multiple regression analysis will be interpreted in the standardized form of the equation as follows:

$$
\mathrm{Y}=0.258+0.135 \mathrm{X} 1+0.270 \mathrm{X} 2+0.515 \mathrm{X3}
$$

The multiple linear regression models can be interpreted as follows:

1. If the value of Advertising increased by $1 \%$ while the other variables are considered to be constant, then the Brand Awareness variable (Y) will increase as much $13.5 \%$.

2. If the value of Personal Selling increased by $1 \%$ while the other variables are considered to be constant, then the Brand Awareness variable (Y) will increase as much $27 \%$.

3. If the value of Social Media Marketing increased by $1 \%$ while the other variables are considered to be constant, then the Brand Awareness variable (Y) will increase as much $51.5 \%$.

Table 2. Result of Multiple Regression

\begin{tabular}{llr|r} 
& \multicolumn{3}{c}{ Coefficients $^{\mathbf{a}}$} \\
\multirow{2}{*}{ Model } & & \multicolumn{2}{c}{ Unstandardized Coefficients } \\
& & B & \multicolumn{2}{c}{ Std. Error } \\
\hline 1 & (Constant) &, 258 &, 180 \\
\cline { 2 - 4 } & A_M &, 135 &, 062 \\
\cline { 2 - 4 } & PS_M &, 270 &, 066 \\
\cline { 2 - 4 } & SMM_M &, 515 &, 074 \\
\hline
\end{tabular}

a. Dependent Variable: BA_M

\subsection{T-Test}

The requirement value that has to be achieved in this T-Test is the significant has to be < 0.05. Based on Table 3, the significant of advertising, personal selling and social media marketing are lower than 0.05 which means:

1. There is partial significant influence of Advertising towards Brand Awareness

2. There is partial significant influence of Personal Selling towards Brand Awareness

3. There is partial significant influence of Social Media Marketing towards Brand Awareness 
Table 3. Result of T-Test

\begin{tabular}{l|l|r|r}
\multicolumn{2}{c}{ Coefficients $^{\mathbf{a}}$} \\
\multicolumn{1}{c|}{ Model } & $\mathrm{t}$ & \multicolumn{1}{c}{ Sig. } \\
\hline 1 & (Constant) & 1,435 &, 154 \\
\cline { 2 - 4 } & A_M & 2,186 &, 031 \\
\hline PS_M & 4,084 &, 000 \\
\hline SMM_M & 6,978 &, 000 \\
\hline
\end{tabular}

a. Dependent Variable: BA_M

1.4 F-Test

Table 4. Result of F-Test

ANOVA ${ }^{\mathrm{a}}$

\begin{tabular}{ll|c|c}
\multicolumn{2}{l|}{ Model } & F & Sig. \\
\hline 1 & Regression & 124,968 &, $000^{\mathrm{b}}$ \\
\cline { 2 - 4 } & Residual & & \\
\cline { 2 - 4 } & Total & & \\
\hline
\end{tabular}

a. Dependent Variable: BA_M

b. Predictors: (Constant), SMM_M, A_M, PS_M

The acceptance or rejection of hypothesis is described as when Significant value $<0.05$, then the Ho rejected and Ha accepted. From the Table 4. above, the result indicates that the significant level is 0.000 , which is lower than 0.05; which means that all of the independent variables (advertising, personal selling and social media marketing) have simultaneously significant influence on dependent variable (brand awareness). 


\subsection{Coefficient of Determination}

Table 5. Result of Coefficient of Determination

\begin{tabular}{l|r|r|r}
\multicolumn{3}{c}{ Model Summary } \\
Model & $\mathrm{R}$ & R Square & $\begin{array}{c}\text { Adjuste } \\
\mathrm{d} \mathrm{R} \\
\text { Square }\end{array}$ \\
\hline 1 &, $869^{\mathrm{a}}$ &, 756 &, 750 \\
\hline
\end{tabular}

a. Predictors: (Constant), SMM_M,

A_M, PS_M

b. Dependent Variable: BA_M

The Coefficient of Determination was essentially measured how far the ability of the model (Advertising, Personal Selling, and Social Media Marketing) to explain the dependent variable (Brand Awareness). From the table 5 above, the adjusted R square is equal to .750 or $75 \%$. This means, there is $75 \%$ of independent variables (Advertising, Personal Selling, and Social Media Marketing) that affect the dependent variable (Brand Awareness) simultaneously. On the other hand, the rest $25 \%$ of Brand Awareness is influenced by others variables which are not examined in this research such as word of mouth and perceived quality.

\subsection{Discussion}

Hypothesis 1 testing result displayed that advertising variable gives influence towards Brand Awareness of Bekasi Industrial Tourism. The significance level of this variable is 0.031 which is below the researcher level of confidence 0.05 . Furthermore, the beta coefficient of advertising is a positive mark at 0.135 means that If the value of Advertising increased by $1 \%$, then the Brand Awareness variable will also increase by $13.5 \%$. This implies that the Advertising is a positive and significant variable that can influence the brand awareness of Bekasi Industrial Tourism. The result is also familiar with the research from Yahya (2014) about The Influence of Advertising towards Brand Awareness and Its Impact on Purchasing Product Decision. It is stated that advertising has a positive and significant impact on the formation of brand awareness.

Hypothesis 2 testing result displayed that Personal Selling variable gives influence towards Brand Awareness of Bekasi Industrial Tourism. The significance level of this variable is 0.000 which is below the researcher level of confidence 0.05. Furthermore, the beta 
coefficient of Personal Selling is a positive mark at 0.270 means that If the value of Personal Selling increased by $1 \%$, then the Brand Awareness variable will also increase by $27 \%$. This implies that the Personal Selling is a positive and significant variable that can influence the brand awareness of Bekasi Industrial Tourism. The result is also familiar with the research from Dewi \& Madgalena (2017) about The Effect of Personal Selling and Word of Mouth toward Brand Awareness. The result shows that personal selling significantly influences brand awareness.

Hypothesis 3 testing result displayed that Social Media Marketing variable gives influence towards Brand Awareness of Bekasi Industrial Tourism. The significance level of this variable is 0.000 which is below the researcher level of confidence 0.05 . Furthermore, the beta coefficient of Social Media Marketing is a positive mark at 0.515 means that If the value of Social Media Marketing increased by 1\%, then the Brand Awareness variable will also increase by $51.5 \%$. This implies that the Social Media Marketing is a positive and significant variable that can influence the brand awareness of Bekasi Industrial Tourism. The result also familiar with the research from Adiguna (2016)about The Influence of Social Media Marketing Towards Brand Awareness. The result found that there is a significant influence of social media marketing towards brand awareness.

Hypothesis 3 testing result displayed that all those independent variables simultaneously have a positive and significant impact on the dependent variable. It was proven by the significance value 0.000 which is less than 0.05 . The Coefficient of Determination has a value 0.756 . This means, there is $7.56 \%$ of Brand awareness that can be explained by independent variables (Advertising, Personal Selling, and Social Media Marketing). The rest 24.4\% are influenced by other factor exclude variable in this research such as word of mouth and perceived quality.

\section{E. Conclusion and Recommendation}

\subsection{Conclusion}

The purpose of this research is to identify whether there is the influence of three independent variables (advertising, personal selling, and social media marketing) towards brand awareness of Bekasi Industrial Tourism. This chapter outlines for main conclusions drawn from statements of the problems through several tests such as Classical Assumptions, Multiple Regression, T-Test, F-Test and The Coefficient of Determination.

According to the analysis and interpretation of Chapter IV, it can be concluded that: 
1. There is partial significant influence of advertising towards brand awareness, which means in partial advertising does influence the brand awareness and makes people aware of Bekasi Industrial Tourism.

2. There is partial significant influence of Personal Selling towards brand awareness, which means in partial Personal Selling does influence the brand awareness and makes people aware of Bekasi Industrial Tourism.

3. There is partial significant influence of Social Media Marketing towards brand awareness, which means in partial Social Media Marketing does influence the brand awareness and makes people aware of Bekasi Industrial Tourism.

4. There is simultaneous significant influence of advertising, personal selling, and social media marketing towards brand awareness of Bekasi Industrial Tourism.

\subsection{Recommendation}

\subsubsection{Bekasi Industrial Tourism}

Based on the detailed analysis of this study, Advertising, Personal Selling, and Social Media Marketing have significantly influence Brand Awareness of Bekasi Industrial Tourism. Therefore, Bekasi Industrial Tourism needs to focus on these promotion strategies in order to make people aware and develop the Bekasi Industrial Tourism.

Researcher intends to recommend few improvements on Bekasi Industrial Tourism:

1. Bekasi Industrial Tourism should further enhance their advertising by creating flyers with the contents that are more interesting and informative so that tourists can be more interested to visit industrial tourism in Bekasi. Adding other types of advertising such as billboards and banners is also a good option in hopes of reaching more people.

2. Conducting training to the marketing of Bekasi Industrial Tourism so that it can work more systematically in order to give confidence to prospective visitors of industrial tourism.

3. Do more frequent updates on social media and also improve the quality of content on social media to grab more public attention.

4. Adding other promotional strategies such as direct marketing and public relations because of the new type of tourism need a vigorous campaign in order to attract the visitors to visit. 


\subsubsection{Future Researcher}

1. Future Researcher is expected to examine other variables outside the variables that have been examined in this research. So, it can be obtained the results that can help to develop the Bekasi Industrial Tourism or other tourism.

2. Future Research is also expected to be done by taking respondents from a different perspective by extending the brand awareness variable to brand image or other variables and add other attributes and using different methods and also use the more complex method as a benchmark for this research.

3. Future studies are advised to examine other tourism destination to analyze the strategy promotion in creating the awareness of the tourist. As the result of the study can be used as comparison and complement to the research.

\section{References}

Adiguna, I. V. (2016) Pengaruh Media Sosial Marketing Terhadap Kesadaran Merek Pada Batagor Hanimun. Undergraduate thesis, Universitas Pendidikan Indonesia.

Chary. (2014). Social Media Marketing-The Paradigm Shift in International Marketing. IOSR Journal of Business and Management, 16(9).

Chow et al., (2017). Building Brand Equity Through Industrial Tourism. Asia Pasific Management Review, 22, 70-79

Dewi, L., \& Madgalena, F. (2017). Pengaruh Personal Selling dan Word of Mouth Terhadap Brand Awareness Bisnis Mahasiswa Universitas Ciputra. Jurnal Eksekutif, 253-261.

Hariyanto. (2018, January 4). Bekasi Industrial Tourism, Destinasi Wisata Industri Pertama di Indonesia Akan Segera Hadir di Bekasi. Retrieved from http://www.industry.co.id/read/22680/bekasi-industrial-tourism-destinasi-wisataindustri-pertama-di-indonesia-akan-segera-hadir-di-bekasi

Herdana, A. (2015). Analisis Pengaruh Kesadaran Merek (Brand Awareness) Pada Produk Asuransi Jiwa Prudential Life Assurance (Studi Pada Pru Passion Agency Jakarta). Jurnal Riset Bisnis dan Manajemen, 3, 1-18.

Huang, R., \& Sarigöllü, E. (2011). How brand awareness relates to market outcome, brand equity, and the marketing mix. Journal of Business Research, 65, 92-99.

Kotler, P., \& Keller, K. L. (2011). Marketing Management 14e. New Jersey: Pearson Education, Inc.

Kusnadi, F. (2010). Pengaruh Bauran Promosi Pada Brand Awareness (Studi Pada Notebook Merk A-Note). Undergraduate thesis, Universitas Kristen Maranatha.

Kusumawardhani, A. (2018, January 6). Mau Wisata di Kawasan Industri? Yuk, Sambangi BIT di Jababeka Cikarang. Retrieved from: http://industri.bisnis.com/read/20180106/12/723841/mau-wisata-di-kawasan-industriyuk-sambangi-bit-di-jababeka-cikarang

Kusumawati. (2010). Analisis Pemakaian Gaya Bahasa Pada Iklan Produk. Fakultas Keguruan dan Ilmu Pendidikan Universitas Sebelas Maret. 
Looy, A. V. (2016). Social Media Management. Cham: Springer International Publishing Switzerland.

Matta, S. (2016). Implementasi Personal Selling oleh Agent dan Downline PT Melilea International Indonesia Cabang Kota Bekasi. Jurnal Visi Komunikasi, 15(2), 262 272.

Maulana, A. (2014). Tinjauan Kesadaran Merek Pariwisata Indonesia "Wonderful Indonesia". Kementerian Pariwisata dan Ekonomi Kreatif, 1.

Melati, F. K. (2016). The Effect Of Social Media On The Brand Awareness At Hotels In Kuta Area. Journal of Business on Hospitality and Tourism, 2(1), 474-482.

Sawant, R. (2012). Impact of Advertising on Brand Awareness and Consumer. IOSR Journal of Business and Management, 5(6), 54-61

Shimp, T. A., \& Andrews, J. C. (2012). Advertising, Promotion, and Other Aspects of Integrated Marketing Communication Ninth Edition. Ohio: Cengage Learning.

Suastika, I. Y., \& Yasa, I. M. (2017, July 7). Pengaruh Jumlah Kunjungan Wisatawan, Lama Tinggal Wisatawan Dan Tingkat Hunian Hotel Terhadap Pendapatan Asli Daerah Dan Kesejahteraan Masyarakat Pada Kabupaten/Kota Di Provinsi Bali. Jurusan Ekonomi Pembangunan Fakultas Ekonomi dan Bisnis Universitas Udayana, 6.

Sugiyono. (2013). Statistika Untuk Penelitian. Bandung: Penerbit Alfabeta Bandung.

Sujarweni, V. W. (2015). Metodologi Penelitian Bisnis Ekonomi. Yogyakarta: Pustaka Baru Press.

Suparwo et al., (2017). Pelaksanaan Personal Selling Dalam Pengaruhnya Terhadap Keputusan Pembelian Polis Asuransi. Ecodemica, 224-251.

Susanto, S. A. (2017). Bekasi Industrial Tourism Proposal. Cikarang: (n.p)

Tsitsi, E. A. (2013). The Adoption of Social Media Marketing in South African Banks. European Business Review, 25(4).

Ulwan, M. N. (2014, February 20). Teknik pengambilan sampel dengan metode purposive sampling. Retrieved from http://www.portal-statistik.com/2014/02/teknikpengambilan-sampel-dengan-metode.html

Warni, S. (2015, December 22). Tahapan Dalam Merencanakan Promosi. Retrieved from https://zahiraccounting.com/id/blog/tahapan-dalam-merencanakan-promosi/

Widiastuti, N. K. (2013). Pengaruh Sektor Pariwisata Terhadap Kinerja Keuangan Daerah Dan Kesejahteraan Masyarakat Kabupaten/Kota Di Provinsi Bali. Undergraduate thesis, Universitas Udayana Bali

Wijaya, A. (2010). Pengaruh Promotional Mix terhadap Brand Awareness pada Produk Honda Beat. Undergraduate thesis, Universitas Kristen Maranatha.

Wulandari \& Triandaru. (2014). Peran Sektor Pariwisata Dalam Pendapatan Asli Daerah Kabupaten Tabanan Tahun 1990-2014. Undergraduate thesis, Universitas Atma Jaya Yogyakarta. 
